DOI: https://doi.org/10.51209/platform.2.4.2021.246-259

УДК 7.793.3(045)

\author{
Володимир Анатолійович ГРЕК, \\ Київська муніципальна академія \\ естрадного та циркового мистецтв, \\ Київ, Україна, \\ e-mail:v.hrek@kmaecm.edu.ua, \\ ORCID: 0000-0002-8622-3082
}

\title{
ПОХІДНІ ТВОРИ В ХОРЕОГРАФІЧНОМУ МИСТЕЦТВІ: НАТХНЕННЯ ЧИ ПЛАГІАТ?
}

Анотація. Створення хореографічних творів багатогранний процес, в якому основними джерелами успіху $є$ майстерність хореографа, можливості виконавців та натхнення, без якого даний процес не дає належного результату. В такому процесі важливо відчувати межу, щоб авторський продукт, натхненний певними творами, не був копією або похідним твором з ознаками копіювання чи плагіату. Саме тоді постає питання недоброчесних запозичень та порушення авторського права в галузі хореографії. Сценічні майданчики конкурсів та фестивалів із хореографічного мистецтва все більше рясніють постановками з ознаками плагіату, і все частіше постає питання привласнення або копіювання чужих хореографічних творів без дозволу автора. Інтернет-платформи наповнені величезною кількістю цікавих постановок, які викликають бажання створити щось подібне, тому після їх перегляду часто відбувається процес наслідування, копіювання, запозичення певних частин композиції, а деколи і цілісної композиційної структури. Часто копіюються постановки 3 телевізійних проєктів, які відомі не тільки в Україні, а й за кордонами нашої держави. Випадки плагіату в хореографії фіксуються не лише на території України, а й за ії межами, що визначає актуальність цього питання на міжнародному рівні. Такі дії у професійній галузі не тільки 
призводять до активізації уваги до проблеми плагіату, а й потребують конкретного алгоритму протидії таким вчинкам.

Стаття присвячена проблемі плагіату в хореографії. У роботі зазначені причини та описані наслідки використання чужого хореографічного матеріалу, розглянуто його невдалу часткову компіляцію та повне копіювання, внаслідок чого порушуються авторські права, а чужі роботи привласнюються. Визначено ознаки плагіату та похідних творів у хореографії на прикладі деяких компонентів танцю або прийомів композиційного рішення. Зосереджено увагу на прикладах апропріації, фактів плагіату та використання чужого хореографічного твору або його складової без згоди автора в розрізі конкурсної та фестивальної діяльності в Україні.

Ключові слова: плагіат у хореографії, похідний твір, авторське право, хореографічне мистецтво, конкурси, фестивалі

Вступ. На сьогодні хореографія є унікальним видом мистецтва, де присутній величезний діапазон взаємодії між автором та глядачем. Контактність мистецтва танцю збагачує духовно та формує риси сприйняття індивідуальності художника через втілення його думок, ідей, образів. Потік, у якому перебуває автор, формує своєрідний унікальний простір, що так само надихає на створення чогось, що матиме вплив на інших людей і підштовхне їх до власних роздумів та надихне, викличе бажання відійти від шаблонного мислення і створити креативний авторський продукт. Але часто такий процес відбувається без натхнення, і тоді постає питання: «Яким чином створити хореографічний твір чи композицію, на чому базуватися й від чого відштовхуватися, щоб розпочати постановочний процес?»

Постановка проблеми. Вдале втілення задуму творів хореографічного мистецтва залежить від професіоналізму автора, його естетичного смаку, світосприйняття та індивідуальних можливостей. Широкий спектр інструментів, за допомогою яких народжується хореографічний твір, формує його індивідуальну траєкторію, створює авторську 
самоідентичність та неповторність. Проте в сучасному світі існує безліч різних прийомів утілення творів мистецтва, в тому числі з використанням напрацювань інших митців, де нерідко такі похідні твори видаються за авторські з формулюванням «Я надихався цією роботою!». Така проблема все частіше зустрічається на сценічних, конкурсних та фестивальних майданчиках України й дедалі більше обговорюється фахівцями-практиками, тому важливо порушити це питання і в розрізі наукової розвідки.

Аналіз останніх досліджень і публікацій. Питання плагіату та недоброчесних запозичень у наукових роботах досліджували, зокрема, Ірина Петренко у своїй праці «Питання виявлення плагіату літературного твору», де розглядається історичний аспект виникнення та поширення плагіату як одного з порушень авторських прав [6, с. 11].

Марина Міщенко у статті «Плагіат як невід'ємна складова залучення людини до екранного простору» визначає поняття плагіату у галузі культури та мистецтва, а також взаємозв'язок збільшення його масштабів, інтенсифікації 3 надмірним споживанням людиною екранної продукції [4, с. 132]. Віра Токарева у своєму дослідженні «Сумлінне використання та похідні твори у сучасному мистецтві» аналізує правові аспекти створення похідних творів, право на перероблення та використання оригіналів у творчості сучасних художників [7, с. 121].

Інна Поліщук досліджує питання підробок та піратства творів мистецтва у своїй роботі «Сучасний стан наукового дослідження підробок та піратства творів мистецтва» [5, с. 275].

Мета статті - визначити ознаки плагіату та похідних творів у хореографії, проаналізувати стан плагіату в хореографічному мистецтві на прикладі використання чужого твору без згоди автора в розрізі конкурсної та фестивальної діяльності в Україні.

Виклад основного матеріалу. Сучасний стан розвитку хореографічного мистецтва представлений широким спектром використання технік, прийомів, композиційних рішень у 248 
балетмейстерській діяльності, що формують індивідуальний мистецький почерк автора та знаходять відбиток у його хореографічних творах. Велика кількість конкурсів та фестивалів створюють унікальну можливість для презентації таких авторських робіт. Але водночас під час їх проведення виникають питання щодо несанкціонованого використання твору чи його складових та привласнення їх без дозволу автора. Порушники нерідко опиняються у центрі скандалу, а їхні незаконні дії призводять до дискваліфікації. Відповідно до п. в) ст. 50 Закону України «Про авторське право та суміжні права» плагіат визначається як оприлюднення (опублікування), повністю або частково, чужого твору під іменем особи, яка не $є$ автором цього твору [2].

Апропріація (привласнення) як явище все частіше зустрічається і в мистецтві, зокрема хореографічному, тому постає питання щодо виявлення ознак плагіату та створення похідних творів у хореографії. Похідним твором мистецтва, відповідно до чинного Закону України № 3792-XI, вважається твір, що $є$ творчою переробкою іншого існуючого твору без завдавання шкоди його охороні (анотація, адаптація, аранжування, обробка фольклору, інша переробка твору) чи його творчим перекладом іншою мовою [1].

Процес постановки хореографічного номеру є складним, і протікає у кожного митця досить індивідуально. Ідея, тема, образи можуть створюватися самостійно або базуватися на літературних творах чи витворах мистецтва. Часом джерелом натхнення слугує кінематограф, але основою $є$ самостійність сценічного рішення як ознаки авторства i приналежності створеного мистецького продукту конкретній особі. Твори мистецтва, що вже існують, та реалізовані хореографічні композиції можуть бути джерелом натхнення. Але де проходить межа між натхненням і плагіатом?

Творчий процес супроводжується особливим станом людини, спрямованим на пошук мотивації, і - як наслідок певних дій, що викликають натхнення. Але чи можна стверджувати, що лише цього стану достатньо і що натхнення 
не потребує додаткової стимуляції? I ось тут на допомогу приходить діджиталізація хореографічного мистецтва і вільний доступ до нього у соціальних мережах. Після перегляду робіт, що вже існують, на рівні підсвідомості можна легко сприйняти побачене як власне i визнати його самостійним рішенням, оскільки процес практичного створення складових танцю передбачає тілесну роботу i відчуття внутрішньої зосередженості на постановочному процесі.

Трапляються випадки, коли готову композицію не просто використовують як наочний відеоматеріал, а частково копіюють, запозичуючи деякі фрагменти лексичного наповнення чи композиційних рішень. Але справжнім фактом плагіату в хореографії є цілком перенесена на інший колектив композиція, без згоди автора, що $є$ яскравим прикладом порушення авторського права постановника. Не краща ситуація i 3 використанням навчально-тренувальних комбінацій, які застосовуються в освітньому, навчальному процесі. Маючи доступ до такого відеоматеріалу в соціальних мережах чи на платформах із відкритим доступом, хореографи часто не просто застосовують такий матеріал як навчальний, a, невдало компілюючи, включають до хореографічних композицій як текстову основу танцю, що не має при цьому ніякої змістовності та відповідності.

Аналізуючи особливості композиційного рішення у хореографії, можна визначити іiі основні компоненти: музична основа хореографічного твору, хореографічний текст (пластичні мотиви танцю), композиційна побудова номеру, художнє оформлення номеру, сценічне вбрання, костюм.

Використання музичної основи для композиції теж порушує питання авторства, оскільки переважна більшість музичних композицій, які обирають для постановки хореографічних творів, мають автора.

«Музичні твори, до числа яких належать, перш за все, пісні, що $\epsilon$ найціннішими об'єктами авторського права, складають основний контент розповсюдження в інформаційнокомунікаційній мережі, а також за допомогою інших 250 
комунікаційних технологій нематеріальних результатів інтелектуальної діяльності, авторські права на які хоча й охороняються чинним законодавством, але в умовах відсутності ефективних механізмів контролю використання таких об'єктів виникає загроза масового порушення зазначених прав відповідних суб'єктів» [3, с. 91].

На жаль, тенденція до використання музичних основ для хореографічних композицій не завжди підкріплена правом використання авторського твору. Це питання наразі жваво обговорюється в мистецькому середовищі. Але, враховуючи складність процесу й морально-етичні цінності, важливим i потрібним було б зазначати прізвище автора обраної музичної основи як факт визнання авторського права на використаний музичний твір.

Претендувати на авторство конкретного руху в танці майже неможливо, але визначення послідовності рухів у комбінаторному поєднанні, підкріплене інтонаційними рішеннями постановника, формує певну авторську концепцію i, відповідно, може претендувати на авторство, закріплене за конкретною особою. Відповідно, послідовність композиційного рішення, малюнків танцю, мізансцен та їхне пластичне відтворення в сценічному просторі теж формують поняття індивідуальної траєкторії втілення творчого задуму та його реалізації. Ще однією з ознак, яку можна віднести до плагіату в хореографії, $€$ художнє оформлення номеру, зокрема копіювання сценічного костюму, враховуючи дизайн, деталі сценічного вбрання та його кольорову гаму.

Високохудожні твори часто стають жертвами плагіату, все більше піддаються копіюванню, формують створення похідних творів, які мають ознаки плагіату i можуть зустрічатися на сценічних майданчиках під час публічної демонстрації. Це питання неодноразово порушувалося фахівцями-практиками в нашій країні і викликало шквал емоцій.

Твори з ознаками плагіату можна побачити на сценічних майданчиках в Україні під час проведення конкурсів та фестивалів. Зокрема на фестивалі хореографічного мистецтва у 
Херсоні була спроба оприлюднити одну з таких робіт. Під час перегляду конкурсних номерів члени журі виявили порушення авторського права роботи, яка мала пряму приналежність до телепроєкту «Танцюють усі». Постановка Тетяни Денисової була перенесена на виконавців колективу 3 м. Запоріжжя. В оцінювальних листах та відповідно до поданої заявки було зазначено, що робота має автора, але дозволу на використання цієї роботи не було. Члени суддівської колегії вирішили не оцінювати цю роботу як таку, що може претендувати на призове місце, враховуючи той факт, що в критеріях оцінювання $є$ розділ «Оригінальність балетмейстерського рішення». Таким чином, відсутність чіткого пункту про порушення авторських прав та використання матеріалу без згоди автора в положенні конкурсу змусили членів журі прийняти рішення відмовити в оцінюванні роботи, яка була знята 3 відео, перенесена на учасників колективу і продемонстрована без згоди його автора.

Приклад порушення авторських прав у хореографії наводить художній керівник хореографічної студії «Fors», викладачка кафедри хореографічного мистецтва Київського національного університету культури i мистецтв Тетяна Винокурова: Виконуючи функції голови журі на фестиваліконкурсі хореографічного мистецтва, вона дискваліфікувала колектив за те, що той представляв на конкурсному перегляді хореографічну композицію, поставлену Тетяною Винокуровою студентам кафедри хореографічного мистецтва спеціально для участі у фестивалі в Іспанії. Оскільки відео цієї постановки було завантажене в соціальні мережі і перебувало у вільному доступі для перегляду, відразу було визнано факт незаконного перенесення його на інший колектив без згоди автора. Організаційний комітет відреагував на ситуацію, i, відповідно до рекомендацій Тетяни Винокурової, було прийняте рішення про дискваліфікацію колективу за порушення авторського права.

Факти порушення авторського права під час конкурсів та фестивалів хореографічного мистецтва в Україні наводить i художня керівниця та засновниця «Totem Dance Group», 
викладачка сучасного танцю, віце-президентка Асоціації «Платформа сучасного танцю України», членкиня журі численних міжнародних та всеукраїнських конкурсів із хореографічного мистецтва Крістіна Шишкарьова. Вона вважає, що плагіат став звичним явищем у царині хореографії. Величезна кількість порушень авторського права, яка фіксується на фестивалях і конкурсах в Україні, говорить про відсутність професійної етики та професіоналізму хореографів узагалі. Копіюються, запозичуються або навіть повністю відтворюються хореографія та цілі постановки не лише українських хореографів, а й колег з інших країн, що дає право стверджувати про порушення авторства вже на міжнародному рівні. Вільний доступ до робіт, викладених у соціальних мережах, не $є$ приводом для використання їх на власний розсуд, і тим паче для привласнення на публіці.

На одному 3 конкурсів, куди К. Шишкарьова була запрошена як членкиня журі, один із колективів цілком використав музичну основу та хореографію з відомого мюзиклу «Барон Мюнхаузен». Його виступ викликав шалені оплески. Проте оцінка Кристини аж ніяк не співпала з реакцією зали, що змусило іï взяти слово і пояснити причини своїх висновків. Найцікавіше те, що керівники колективу свої дії пояснювали тим, що вони використали матеріал із диска, який придбали раніше. Сенсу дискутувати далі суддя не бачила, хоча зразковому колективу було 15 років...[8].

Висновки. Підбиваючи підсумки, ми маємо підстави стверджувати про наявність плагіату та використання чужого хореографічного твору чи його складової без згоди автора на прикладах конкурсної та фестивальної діяльності в Україні. Ефективним засобом запобігання порушенню авторських прав на таких заходах є дискваліфікація учасників, які привласнюють чужі роботи та видають їх за свої. Проте, перш ніж зафіксувати факт плагіату й визначити приналежність твору певному автору, важливо детально дослідити це питання, спираючись на конкретні факти та докази. Такі випадки непоодинокі, тому постає питання про створення спеціального пункту в 
положеннях про конкурси і фестивалі, де б чітко визначалася відповідальність і описувалися можливі наслідки для порушника авторських прав при виявленні ознак плагіату.

Констатація цих фактів окреслює коло проблемних питань, пов'язаних із порушенням авторських прав та недоброчесних запозичень i боротьби 3 цим явищем. Не зважаючи на безумовну необхідність захисту власних творчих доробок у хореографічному мистецтві, необхідні подальші дослідження проблематики питання не лише з юридичної, а й $з$ практичної точки зору, створення чітких покрокових інструкцій при оформленні свідоцтва про реєстрацію авторських прав на хореографічний твір, що захистить хореографів від копіювання та присвоєння їхніх робіт. Натхнення повинне залишатись інструментом для створення унікальних, оригінальних авторських робіт, а не об'єктом порушення прав інтелектуальної власності. Це питання широко обговорюється у професійному середовищі, воно дотичне до галузі конкурсної та фестивальної діяльності, потребує розроблення конкретного алгоритму дій задля запобігання порушень авторських прав у хореографії та мистецькій царині загалом.

\section{Список використаної літератури:}

1. Закон України № 3792-XI.

URL: https://ips.ligazakon.net/document/TM005263

2. Закон України Про авторське право і суміжні права. Розділ V. Стаття 50.

URL: http://www.intellect.ua/ukr/copyright/law/laws/copyright/V/50 3. Кривенко М. До питання захисту авторських прав на музичні твори в мережі інтернет. Национальный юридический журнал: теория и практика. 2017. Сс. 90-92.

4. Міщенко М. Плагіат як невід'ємна складова залучення людини до екранного простору. Культурологічна думка. 2018. № 13. Сc. $132-137$.

5. Поліщук I. Сучасний стан наукового дослідження підробок та піратства творів мистецтва. Український 
мистецтвознавчий дискурс: колективна монографія. НАКККІМ. Рига: Izdevniecība «Baltija Publishing». 2020. Сc. 278-291.

6. Петренко I. Питання виявлення плагіату літературного твору. Теорія і практика інтелектуальної власності. 2009. Вип. 4. Cc. 11-17.

7. Токарева В. Сумлінне використання та похідні твори у сучасному мистецтві. Цивільне право і цивільний процес; сімейне право; міжнародне приватне право. - Т. 31 (70), ч. 1, № 2. 2020. С. 121.

8. Шишкарьова К.

URL: https://totemdancegroup.com.ua/kristina-shishkareva-plagiatstal-ochen-obychnym-yavleniem-v-srede-xoreografii-26-06-12/

\section{Владимир Анатольевич ГРЕК,}

Киевская муниципальная академия

эстрадного и циркового искусств,

Киев, Украина, e-mail: v.hrek@kmaecm.edu.ua, ORCID: 0000-0002-8622-3082

\section{ПРОИЗВОДНЫЕ ПРОИЗВЕДЕНИЯ В ХОРЕОГРАФИЧЕСКОМ ИСКУССТВЕ: ВДОХНОВЕНИЕ ИЛИ ПЛАГИАТ?}

Аннотация. Создание хореографических произведений - многогранный процесс, в котором основными источниками успеха являются мастерство хореографа, возможности исполнителя и вдохновение, без которого данный процесс не дает должного результата. В таком процессе важно чувствовать грань, чтобы авторский продукт, вдохновленный определенными произведениями, не был копией или производным произведением с признаками копирования или плагиата. Именно тогда возникает вопрос нечестных заимствований и нарушения авторского права в сфере хореографического искусства. Сценические площадки конкурсов и фестивалей хореографического искусства все 
больше пестрят постановками с признаками плагиата, и все чаще возникает вопрос присвоения или копирования чужих хореографических произведений без разрешения автора. Интернет-платформы наполнены огромным количеством интересных постановок, которые вызывают желание создать что-то подобное, поэтому после их просмотра часто происходит процесс подражания, копирования, заимствования определенных частей композиции, а порой и целостной композиционной структуры. Часто копируются постановки из телевизионных проектов, которые известны не только в Украине, но и за рубежами нашей страны. Случаи плагиата в хореографии фиксируются не только на территории Украины, но и за ее пределами, что определяет актуальность этого вопроса на международном уровне. Такие действия в профессиональной сфере не только приводят к активизации внимания к проблеме плагиата, но и требуют конкретного алгоритма действий для противодействия таким поступкам.

Статья посвящена проблеме плагиата в хореографии. В работе указаны причины и описаны последствия использования чужого хореографического материала, рассмотрена его частичная компиляция или полное копирование, вследствие чего нарушаются авторские права, а чужие работы присваиваются. Определены признаки плагиата и производных произведений в хореографии, на примере некоторых компонентов танца или приемов композиционного решения. Сосредоточено внимание на примерах апроприации, фактов наличия плагиата и использования чужого хореографического произведения или его составляющей без согласия автора в конкурсной и фестивальной деятельности в Украине.

Ключевые слова: плагиат в хореографии, производное произведение, авторское право, хореографическое искусство, конкурсы, фестивали 


\author{
Volodymyr A. GREK, \\ Kyiv Municipal Academy \\ of Circus and Performing Arts, \\ Kyiv, Ukraine, \\ e-mail: v.hrek@kmaecm.edu.ua, \\ ORCID: 0000-0002-8622-3082
}

\title{
DERIVATIVE WORKS IN CHOREOGRAPHIC ART: INSPIRATION OR PLAGIARISM?
}

\begin{abstract}
Creation of choreographic works is a multifaceted process in which the main sources of success are the skills of the choreographer, the ability of the performer and inspiration, that is needed to get the desired result. In this process, it is important to feel the edge so that your own product, inspired by certain works, will not become a copy or a derivative work that will show signs of copying or plagiarism. It is then that the question of dishonest borrowing and copyright infringement in the field of choreographic art arises. Stages of competitions and festivals in choreographic art are increasingly replete with productions having signs of plagiarism and increasingly raise the issue of misappropriation or copying of other people's choreographic works without the permission of the author. Internet platforms are filled with a huge number of interesting productions that make you want to create something similar, so when you watch them, there is often a process of imitation, copying, borrowing certain parts of the composition, and sometimes the whole compositional structure. Productions from television projects, which are known not only in Ukraine but also abroad, are often copied. Cases of plagiarism in choreography are recorded not only in Ukraine but also abroad, which determines the relevance of this issue at the international level. Such actions in the professional sphere not only lead to increased attention to the problem of plagiarism, but also require a specific algorithm of actions to combat such acts.

The article is dedicated to the problems of plagiarism in choreography. The work outlines the causal consequences of using
\end{abstract}


someone else's choreographic material, its partial compilation or full copying, which in turn leads to copyright infringement and the appropriation of other people's works, presenting them as their own. The signs of plagiarism and derivative works in choreography are determined on the example of some components of dance, or methods of compositional solution. Attention is focused on examples of appropriation, facts of plagiarism and the use of someone else's choreographic work or its component without the consent of the author in the context of competitive and festival activities in Ukraine.

Key words: plagiarism in choreography, derivative work, copyright, choreographic art, contests, festivals

\section{References:}

1. Zakon Ukrajiny № 3792-XI [Law of Ukraine № 3792-XI] Available at: https://ips.ligazakon.net/document/TM005263 [in Ukrainian]

2. Zakon Ukrajiny Pro avtors'ke pravo i sumizhni prava. Rozdil V. Stattja 50

[Law of Ukraine on Copyright and Related Rights. Part V. Article 50]

URL: http://www.intellect.ua/ukr/copyright/law/laws/copyright/V/50 [in Ukrainian]

3. Kryvenko, M. (2017). Do pytannja zahystu avtors'kyh prav na muzychni tvory $\mathrm{v}$ merezhi internet [On the protection of copyright of musical works in the Internet]. Natsional'nyy yuridicheskiy zhurnal: teoriya i praktika. 2017, 90-92 [in Ukrainian] 9. 4. Mischenko, M. (2018). Plagiat jak nevid'jemna skladova zaluchennja ljudyny do ekrannogo prostoru. [Plagiarism as an integral part of human involvement in the screen space] Kul'turologichna dumka, 13, 132-137 [in Ukrainian]

5. Polischuk, I. (2020). Suchasnyj stan naukovogo doslidzhennja pidrobok ta piratstva tvoriv mystectva. Ukrajins'kyj mystectvoznavchyj dyskurs: kolektyvna monografija. NAKKKIM. - Ryga: Izdevniecība "Baltija Publishing" [The current state of scientific research of counterfeits and piracy of works of art. 
Ukrainian art criticism discourse: a collective monograph], 278-291 [in Ukrainian]

6. Petrenko, I. (2009). Pytannja vyjavlennja plagiatu literaturnogo tvoru. Teorija i praktyka intelektual'noji vlasnosti [The issue of detecting plagiarism of a literary work], 4, 11-17 [in Ukrainian]

7. Tokareva, V. (2020). Sumlinne vykorystannja ta pohidni tvory u suchasnomu mystectvi. Cyvil'ne pravo i cyvil'nyj proces; simejne pravo; mizhnarodne pryvatne parvo [Conscientious use and derivative works in contemporary art. Civil law and civil proceedings; family law; international private law], 2, 121 [in Ukrainian]

8. Shyshkarova, K. Available at:

https://totemdancegroup.com.ua/kristina-shishkareva-plagiat-stalochen-obychnym-yavleniem-v-srede-xoreografii-26-06-12/

[in Russian] 